\title{
Research on University Library Service Innovation Strategy Based on Maker pace
}

\author{
Haiyan Liu ${ }^{1,}$, , Yongwen Zhong 2, b \\ ${ }^{1}$ Information Technology Institute, Jilin Agricultural University, Changchun 130117, China; \\ ${ }^{2}$ The Library of Jilin Province, Changchun 130117, China. \\ a53328535@qq.com, b12222728 @qq.com
}

Keywords: Maker space, University Library, Service innovation.

\begin{abstract}
This paper introduces the concept of makerspace, analyses its important value, and on this basis, this paper discusses the advantages and meaning of university library to introduce a maker space, creates the maker space of university library in China's" four services "point of view, this paper expounds the present situation of the development of university library and the maker space, points out the deficiency existing in university library and the makerspace in our country at present stage, and finally, from the scope of service object, physical space construction, virtual platform construction and talent service aspects such as strategic planning, related suggestions are given.
\end{abstract}

\section{Introduction}

University library is the core of document information, it retains and transmits a large number of intelligence information, in the high talent cultivation and scientific research plays an important role. Along with continuous improvement of science and technology and the fast development of information society, colleges and universities is not only bear the function of higher education, also bear the open society, service oriented the important role of ordinary citizens. "Maker" refers to a person who is trying to turn ideas into reality without making money. The first is a social platform for users to exchange experiences and share resources. Makerspace appear early only as communication provides a guest book, share the achievements of knowledge space, gathered in the guest room of people with the same or similar interests and hobbies, they exchange experience here, sharing resources, co-creation, efforts to achieve their own ideas.

\section{The university library establishes the meaning of creating maker space}

\subsection{The university library establishes the advantage of maker space}

\subsubsection{Physical advantages}

Compared with other departments in the colleges and universities, the library has a relatively large physical space, and university library has paid attention to the construction of various seminar room, as the interest group and the project team to provide research discussion space, the open seminar room has some of the traits of the maker room. The library is renovated by the space, can make room for creating maker space, so the university library is more suitable to develop the service that creates guest space.

\subsubsection{Resource advantage}

The university library, as the information service center of the university, has extensive information reserves, which can guarantee each user to share the library literature, technology and other resources. These vast quantities of information can bring together a large pool of talented people to build a platform for communication.

\subsection{The university library establishes the meaning of maker space}

The library will be introduced into the library, which will provide a new platform for the teaching and innovation of colleges and universities. In knowledge learning and sharing, and maker space not 
only spare space using the library resources, also make the library's literature resources get greater development and use.

2.2.1 Fully tap the value of library resources.

The resources of academic libraries are limited to the literature resources, but in fact, the resources of university libraries include physical resources, human resources and equipment resources. Creating maker space is not only the need for library documentation resources, but also the physical resources, talent resources and equipment resources that are essential to the creation of customer activities.

2.2.2 Expanding the scope and effectiveness of Library Services.

The university library can use their own advantages exist, will provide services ranging from after-school learning places for students, extended to students entrepreneurial base, communicate with social enterprises and individuals, conditions and business resources required in accordance with these organizations to provide innovative services, providing opportunities for free creative learning. This will not only play the potential value of university libraries, but also improve the popularity of colleges and universities and improve their influence.

2.2.3 The Status of Libraries in Colleges and Universities is improved.

The library maker space broke the traditional forms of learning, provide communication opportunities for innovation and the place for the professional personnel, the introduction of advanced technology equipment, has abundant resources, so that university library is no longer as "keep quiet, their learning space, but can broaden their horizons, learn new places to learn from each other. To a certain extent, the creation of "guest space" has raised the status of Libraries in Colleges and universities and made them the core of the University's knowledge storage.

\section{Problems existing in the construction of maker space in University Libraries}

At present in our country has been carried out maker space activities there are many universities, such as Tsinghua University, Zhejiang University, Tianjin University, Shandong University, Southwest Jiao Tong University, East China University of Science and Technology and other schools, mostly by the scientific research department, science and Technology Park, faculty, student groups and enterprises, social structure and other joint aircraft hit. But the real lead by the university library to build a guest space is rare. The main reason is that the construction of creative maker space in our country is at the stage of exploration.

\subsection{Limited service objects}

At present, the service object of the creation of a guest space in the university library is a formality for the students and teachers of the university. Compared to the rest of the school library service content, service objects of university library should not for a single group between teachers and students, but all has high quality innovative talents. Only by opening the doors of university libraries to the higher classes are more conducive to the collision of knowledge and the development of the creative space of the university library.

\subsection{Insufficient service conditions}

First of all, in the allocation of resources, China's academic libraries create a maker space, hardware and software facilities are not comprehensive enough. The conditions for creating customers are limited. The physical space planning is not reasonable, and it is a bold decision to load the elements of the creative space into the library, but it is also the inevitable result of the development of the times.

\subsection{Single service item}

University Libraries in our country have started a relatively late start, and the service items are limited to document sharing, electronic reading and multimedia learning and research. The function of Libraries in Colleges and universities is unitary. Based on the service function of traditional libraries, they cannot be regarded as the maker spaces for residents in the full sense. It is necessary for university libraries to innovate and transform according to their own advantages and characteristics. 


\subsection{Lack of service personnel}

In the present stage of our country is still the ordinary librarian is equivalent to the service personnel, in fact, increase maker space elements of library service personnel requirements increases, with simple librarians has been unable to meet the University Library maker space operation requirements, should be more professional service personnel.

\section{Suggestions on constructing maker space in University Libraries}

\subsection{Expand the scope of service objects}

The service object of the university library has been expanded from a single school to creative elite in every field. The expansion of the service object is the first to increase the value of the high-efficiency application of the university library. From another point of view, the increase of the maker space service object of the university library will surely improve the efficiency of the transformation of the resource.

\subsubsection{Start an exchange day activity}

As the knowledge reserve center of universities, the rational exchange of daily activities will promote the dissemination of culture and the exchange of information. The open exchange day provides an innovative foundation for the maker elite from all walks of life, and improves the utilization rate of library space while increasing the exchange rate between university teachers and students and the outside world.

\subsubsection{Constructing a network sharing system of resources}

The construction of network resources sharing system is the University Library maker space resources integration in the campus network system, to focus the different social identities and different distance in creating maker space can make the same record off exchange activities.

\subsection{Improve physical space construction}

The creation space is different from the traditional seminar room in the library, the traditional seminar room only has basic tables and chairs and multimedia projection facilities. As a place of cooperation and innovation, the maker has a more open learning environment and a higher requirement for physical space. In the construction of the library, it should also pay attention to the particularity of the traditional library environment. The maker space is an open free space, is bound to subversion of the traditional library quiet, quiet environment, so pay attention to the reasonable layout and the construction of the sound insulation facilities.

\subsection{Enhancing virtual platform construction}

Along with the Internet of things, cloud computing, big data as a representative of a new generation of the development of information technology, information system has been built and an indispensable part of the passenger space. The virtual platform of creating guest space mainly shows three aspects: education platform, project management platform and daily communication platform.

4.3.1 Online education platform

In conventional subject service in theory and practice of the course, accumulated the massive process content, the basis of systematically the integrated development and integration, can make a constantly evolving ability of curriculum system. The founder can learn and master the skills according to the need. In the case of good maker, you can also combine specific content, develop new courses, and upgrade course system.

4.3.2 Project management platform

Maker space as a place of invention, it requires a formal project management platform, from the development of the project, the interim updates to the completion of the final project. A project that runs from the beginning to the end will be an integral part of the project management platform.

\subsubsection{Daily communication platform}

Traditional library exchange susceptible to time and space constraints, the guest room to join daily communication platform can let a guest at any time and place for the exchange of knowledge. This is not only accelerated the pace of knowledge innovation and technological upgrading, and also in some 
extent, is one of the library and the guest room publicity channels, and make it more integrated into people's lives.

\subsection{Attach importance to talent service construction}

The user is the main body that the university library builds the creation of the maker space; the purpose is to provide sufficient support and safeguard for the creativity, satisfy the innovation demand. Long-term sound and maker space need to complete the team work and running management mechanism, the university library and the maker space need to attract high-quality teaching resources of colleges and universities and a good guest and entrepreneurs such as guidance, establish a multidisciplinary background of entrepreneurial innovation education personnel.

\subsubsection{Subject librarian}

Students are required to support services in the course of the project. Such services can be tracked and supported by librarians in the library.

4.4.2 Teachers' team

Collection of each college school teacher to hit a knowledge guidance project, maker teachers according to their knowledge reserves and expertise, guide the maker student, knowledge foundation for it.

4.4.3 Gen maker elite

Invite well-known experts in the society to join and serve as the project instructor, to guide the students' creative activities, and to participate in the creative activities. Students can be exposed to the latest work ideas and techniques without being able to get out of campus.

\section{Conclusion}

The library is a creative workshop for creative projects to promote entrepreneurship and the wisdom of economic development. College libraries have superior physical condition and resource advantage, carry out a space to meet the need of the social innovation, and meet the requirement of the development of the library itself. The introduction of the university library will promote the education and learning of the masses, communities and schools, which will help to create and cultivate new intellectual communities for the society. Therefore, the construction of university library should develop a maker space, attract creative talents, to establish good customer innovation development platform, make the university library for service transformation actively, is conducive to good library undertaking development.

\section{References}

[1]. Hairong Ding, Wangjun. Maker space: the new way of social service of university library. Sichuan library journal. Vol. 42 (2016) No. 3, p. 38-41.

[2]. Zhimin Jin. Innovation in the creation of maker space and library service model. Library journal.VOL.68 (2015) NO.7, P.78-82.

[3]. Jianhui Sun. The university library " maker space" build research and practice exploration. Library theory and practice. VOL.89 (2016) NO.2, P.17-25. 